\begin{tabular}{|l|l|l||}
\hline \multicolumn{2}{|c|}{ PublisherInfo } \\
\hline \hline PublisherName & $:$ & BioMed Central \\
\hline \hline PublisherLocation & $:$ & London \\
\hline \hline PublisherImprintName & $:$ & BioMed Central \\
\hline \hline
\end{tabular}

\title{
Heterochromatin interactions
}

\begin{tabular}{|l|l|l||}
\hline \multicolumn{2}{|c|}{ ArticleInfo } \\
\hline \hline ArticleID & $:$ & 4027 \\
\hline \hline ArticleDOI & $:$ & $10.1186 /$ gb-spotlight-20010323-04 \\
\hline \hline ArticleCitationID & $:$ & spotlight-20010323-04 \\
\hline \hline ArticleSequenceNumber & $:$ & 98 \\
\hline \hline ArticleCategory & $:$ & Research news \\
\hline \hline ArticleFirstPage & $:$ & 1 \\
\hline \hline ArticleLastPage & $:$ & 2 \\
\hline \hline & & RegistrationDate : 2001-03-23 \\
ArticleHistory & $:$ & OnlineDate \\
\hline \hline ArticleCopyright & $:$ & BioMed Central Ltd2001 \\
\hline \hline ArticleGrants & $:$ & \\
\hline \hline ArticleContext & $:$ & 130592211 \\
\hline \hline
\end{tabular}




\section{Jonathan B Weitzman}

Email: jonathanweitzman@hotmail.com

The human AF10gene has been associated with chromosomal translocation in acute leukemias. In the March 15 EMBO Reports, Linder et al. describe their study of the Drosophila AF10 homolog, dAF10, in an attempt to understand its function (EMBO Reports 2001, 2:211-216). They isolated the $d A F 10$ gene from a database screen and show that it codes for four transcripts that are differentially expressed during fly embryogenesis. The dAF 10 protein contains a PLVVL pentamer motif that mediates interaction with the fly heterochromatin protein 1 (HP1), which is encoded by the $S u(v a r) 2-5$ gene. Linder et al. characterized mutations of the $d A F 10$ gene to demonstrate that dAF10 is a functional repressor component of heterochromatin and that the gene genetically interacts with $\mathrm{Su}(\mathrm{var}) 2-5$ in suppression of position effect variegation (PEV).

\section{References}

1. The $t(10 ; 11)$ translocation in acute myeloid leukemia (M5) consistently fuses the leucine zipper motif of AF10 onto the HRX gene.

2. Translocations, fusion genes, and acute leukemia.

3. EMBO Reports, [http://embo-reports.oupjournals.org/]

4. Berkeley Drosophila genome project, [http://www.fruitfly.org/]

5. The HP1 chromo shadow domain binds a consensus peptide pentamer.

6. The Polycomb protein shares a homologous domain with a heterochromatin-associated protein of Drosophila. 